Annals of Warsaw University of Life Sciences - SGGW

Land Reclamation No 43 (2), 2011: 143-153

(Ann. Warsaw Univ. of Life Sci. - SGGW, Land Reclam. 43 (2), 2011)

\title{
BOD measuring and modelling methods - review
}

\author{
TADEUSZ SIWIEC, LIDIA KIEDRYŃSKA, KLAUDIA ABRAMOWICZ, \\ ALEKSANDRA REWICKA, PIOTR NOWAK \\ Department of Civil Engineering, Warsaw University of Life Sciences - SGGW
}

\begin{abstract}
B O D$ measuring and modelling methods - review. The article presents the method of measuring BOD in wastewater and characteristic different models which can by used for describing changes of BOD in next days. In the paper described eight models: Moore et al. (1950), Thomas (1950), Navone (1960), Fujimoto (1964), Hewitt et al. (1979), Adrian and Sanders (1992-1993) as well as Young and Clark (1965) used by Adrian and Sanders (1998), Borsuk and Stow (2000) and Manson et al. (2006). Comparison the models suggests that changing of BOD during the time are better describes by models second order or double exponential model (Manson et al. 2006) than models the first order.
\end{abstract}

Key words: $\mathrm{BOD}_{5}, \mathrm{BOD}_{\text {total, }}$ mathematical modelling, wastewater.

\section{INTRODUCTION}

The biochemical oxygen demand (BOD) is an indicator used to evaluate the degree of the contamination of water and sewages with the organic substances. Although it is much faster to indicate the chemical oxygen demand (COD) and the total organic carbon (TOC), it is difficult to resign the indication of BOD and more precisely the five-day $\mathrm{BOD}\left(\mathrm{BOD}_{5}\right)$ because it informs about the concentration of the organic substances decomposed in the biological way. The acceptance of the five-day biological oxygen demand
$\mathrm{BOD}_{5}$ is caused by the fact that during the first 5 days there is a decomposition of $60-70 \%$ of the organic substances (Gajkowska-Stefańska et al. 1994). The course of changes in BOD for the first five days of incubation at the temperature of $293 \mathrm{~K}\left(20^{\circ} \mathrm{C}\right)$ can show how effectively the processes of self-purification of water in rivers will take place and the course and the effectiveness of wastewater treatment of sewages in the oxygen reactors in the sewage treatment plants. The total aerobic decomposition of organic compounds occurs for about 100 days. Whereas during the first period of about 20 days there is the decomposition of carbohydrates and then other compounds including the organic nitric compounds (Kiedryńska et al. 2006).

The measurement of BOD can be made withtheuseofdifferentmethods. Themethod of dilution is a classic method which is labour-consuming but its unquestionable value is the high accuracy resulting from the precision of the measurement of the oxygen concentration with the Winkler method (Gajkowska-Stefańska et al. 1994). The next methods are the manometric method of Sierp and Warburg and the automatic methods which can also include the method with the use of the 
Sapromat (Gajkowska-Stefańska et al. 1994). Tebbutt and Berkun (1976) used the respirometric method stating that it depends on the capacity of the sample and that with reference to the standard method they received the correct results at the capacity of 100 up to $150 \mathrm{ml}$. The modification of the standard method of dilution was suggested by Xinglong and Boyd (2005). The modification suggested that the sample should be aerated up to the oxygen concentration of about $8 \mathrm{mgO}_{2} \cdot \mathrm{dm}^{-3}$ and incubated for the definite time. When the oxygen concentration decreased too much, the sample was aerated again to the similar concentration and it was incubated again. Such a procedure was repeated in the next days. In this way, owing to the aeration the oxygen conditions in the sample were provided all the time, and total $\mathrm{BOD}_{5}$ was achieved by adding up the use of oxygen in the individual stages. As the authors claim, the result, in the procedure, was very similar to the result received in the method of dilution.

Various researchers used the selected microorganisms to examine the decomposition of the organic compounds and to control the kinetics of the oxygen use. Testing Trichosporon cutaneum, Sohn et al. (1995) found out the decreasing linear dependence between the concentration of the dissolved oxygen and the concentration of the analysed organic substances. The bacteria Pseudomonas putida were used by Chee et al. (2000) examining the dependence of the potential expressed in $\mathrm{mV}$ as a function of concentration of BOD. They found out the high precision of the measurement in comparison with the standard methods, even at so low the values of BOD as
$1 \mathrm{mgO}_{2} \cdot \mathrm{dm}^{-3}$. The measurement was not accurate between $0.5 \quad \mathrm{mgO}_{2} \cdot \mathrm{dm}^{-3}$ and $1.0 \mathrm{mgO}_{2} \cdot \mathrm{dm}^{-3}$ because the estimated error equaled $20 \%$. The biosensors for the online measurement indicated a very good conformity with the standard methods and the linear dependence in the scope from $5 \mathrm{mgO}_{2} \cdot \mathrm{dm}^{-3}$ up to $700 \mathrm{mgO} \cdot \mathrm{dm}^{-3}$ (Liu et al. 2004).

Reynolds and Ahmad (1997) suggested a non-invasive method of the BOD measurement through the analysis of absorbance and the fluorescence effects during the sample irradiation. They found out that there is a linear dependence of the BOD concentration on the intensity of fluorescence of the wave length of $340 \mathrm{~nm}$ inducing the sample with the irradiation with the wave of $280 \mathrm{~nm}$ long.

One of latest methods is the use of the system Oxi Top Control which defines the use of oxygen through the measurement of the pressure changes (Kiedryńska et al. 2006).

\section{MODELLING OF BOD}

The changes in the oxygen concentration in the surface water are described with the equation of Streeter and Phelps and they depend on saturation, reaeration and changes in the concentration of the contaminations described by BOD (Adrian and Sanders 1992-1993). The modelling of the BOD variety can be described with the equation of the half order (the index of 0.5) (Adrian and Sanders 1992-1993) and the first or the second one (Adrian and Sanders 1998). In both publications Adrian and Sanders (1992-1993; 1998) showed that they did not receive significant differences in the results with the use of the equations 
of the above mentioned orders in their research.

The following equation is most often used to model the course of the BOD variety (1)

$$
\frac{d y}{d t}=k \cdot y
$$

which is presented in the form (2) in some publications

$$
\frac{d(L-y)}{d t}=K \cdot(L-y)
$$

or in the form (3) (Fujimoto 1964)

$$
\frac{d y}{d t}=K \cdot(L-y)
$$

where:

$y$ - BOD value at any time $t$,

$L$ - total BOD, whereas $k$ and $K$ the constant reactions.

The function of $y(t)$ is increasing whereas $(L-y)(t)$ decreasing which is presented in the qualitative way (without the axis calibration) in the diagram in Figure 1.

Sheehy (1960) tried to indicate the constant $K$ using the results of the BOD measurement after the first 24-hour incubation, the second one, etc. Analysing the results, he found out that $K$ does

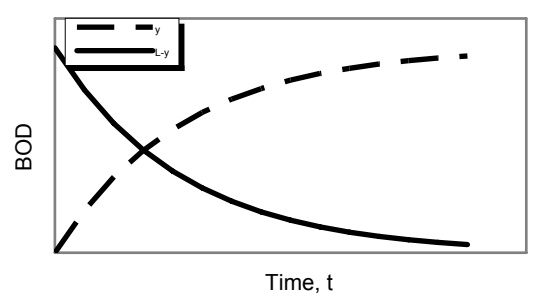

FIGURE 1. Tendency of changes in the dependence of "y" and "L-Y" on time (Keshavan et al. 1965) not always have the constant value. $\mathrm{He}$ assumed $K_{5}$ as a reference point or $K$ calculated with reference to the fifth day and he presented that if $K_{1 / 5}=K_{2 / 5}=\ldots=K_{8 / 5}$, there is the reaction of the first order and this case exists as was stated by Marske and Polkowski (1972), when $K \leq 0.2$. If $K_{1 / 5}<K_{2 / 5}<\ldots<K_{8 / 5}$, there is a lag in the decomposition reaction and then Sheehy suggested that the calculations should be made without the changes occurring on the first day. However, if $K_{1 / 5}>K_{2 / 5}>\ldots$ $>K_{8 / 5}$, the initial significant consumption of oxygen shows the high concentration of organic substances decomposed easily.

After integrating the equation (3) Fujimoto (1964) received

$$
\frac{L-y}{L-y_{0}}=e^{-k \cdot t}=10^{-K \cdot t}
$$

where $y_{0}$ is a $\mathrm{BOD}_{5}$ value at the time $t=0$.

Constructing the dependence diagram $y(t)$ in the function $y(t+1)$, he received the rectilinear dependence (Fig. 2), which enabled the indication of the function gradient and the intersection point of the vertical axis and the parameter $k$ and $L$ on their basis.

Thomas (1950) suggested the function which allows to receive the dependence while being developed in the series:

$$
\left(\frac{t}{y}\right)^{1 / 3}=\frac{1}{(2.3 \cdot k \cdot L)^{1 / 3}}+\frac{(2.3 \cdot k)^{2 / 3}}{6 \cdot L^{1 / 3}} \cdot t
$$

This dependence marked on the diagram of the horizontal axis $t$ and the vertical one $\left(\frac{t}{y}\right)^{1 / 3}$ becomes the linear function, which allows to define the 


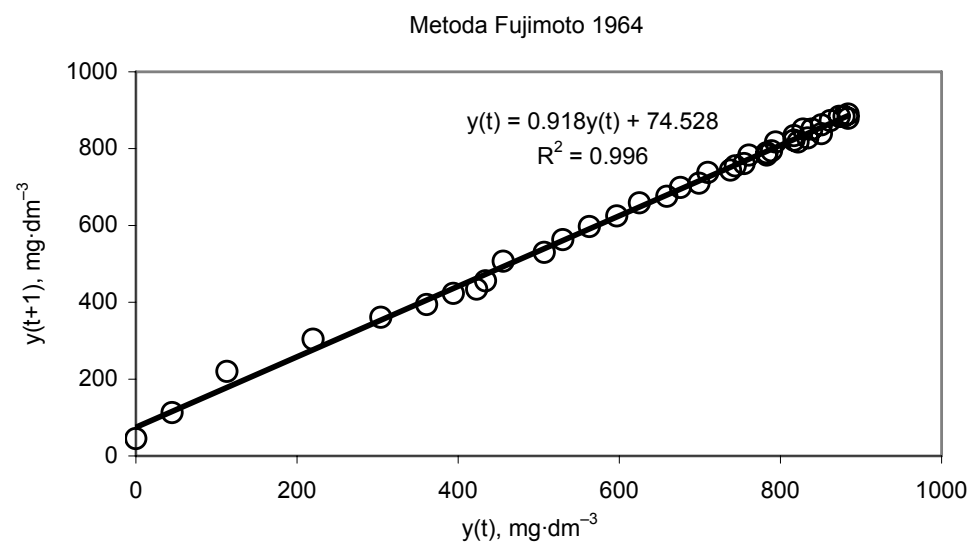

FIGURE 2. The picture of the function graph according to the Fujimoto model (1964) [to picture it, the measurement points received in the own research were used (Siwiec et al. 2011)]

intersection point $A$ (the free expression) and its inclination $B$ (the expression at the variable $t$ ). The knowledge of $A$ and $B$ allows to calculate $k$ and $L$ on the basis of the formulas (6):

$$
\begin{aligned}
& k=\frac{2.61 \cdot B}{A} \\
& L=\frac{1}{2.3 \cdot k \cdot A^{3}}
\end{aligned}
$$

Navone (1960) using the formula (3) suggested the following method of procedure. After comparing the time measurement $t_{i}$ in the first column and the BOD value written as $y_{i}$ in the other one, the third one should be constructed in which the results of the calculation $\frac{d y}{d t}$ calculated according to the formula (7) where:

$$
\frac{d y_{i}}{d t_{i}}=\frac{y_{i+1}-y_{i-1}}{t_{i+1}-t_{i-1}}
$$

Constructing the diagram $\frac{d y_{i}}{d t_{i}}$ in the function of $y_{i}$, the linear dependence is received, which allows to mark the inclination, i.e. the constant of the reaction $k$ and the intersection point of the vertical axis $\frac{d y_{i}}{d t_{i}}=a$. Hence, $L-$ can be calculated, which equals $\frac{a}{k}$. As the author states, this method gives the results very similar to the results received in the method described by Moore et al. (1950).

Moore et al. (1950) elaborated the diagrams of two vertical axes where one was marked with the values $\frac{\sum y}{\sum(t \cdot y)}$, and the other one $\frac{\sum y}{L}$. The horizontal axis was the constant of the reaction , $k$ ". Therefore the diagram made $\frac{\sum y}{\sum(t \cdot y)}=$ $=f(k)$ and $\frac{\sum y}{L}=f(k)$. The authors elaborated the separate diagrams for $\mathrm{BOD}_{3}, \mathrm{BOD}_{5}$ and $\mathrm{BOD}_{7}$. Consequently, knowing the results of the experimental research for the given case, $\sum y$ and $\sum(y \cdot t)$ can be calculated and $k$ and $\frac{\sum y}{L}$ can be 
read from the diagram which allows to calculate $L$.

Moore et al. (1950) also elaborated the method to calculated the length of the lag phase of the BOD growth in the time function suggesting the application of the model according to the formula:

$$
y=L \cdot\left(1-10^{-k \cdot\left(t+t_{0}\right)}\right)
$$

The calculation of " $L$ ", " $k$ " and " $t_{0}$ " was suggested with the application of the prepared diagram by the authors. Other researchers, analyzing the graph of the measurement points depicting the changes of BOD in the time function, suggested their division into the individual parts (Keshavan 1965; Young and Clark 1965; Swamee and Ojha 1991) distinguishing the cases with the lag phase. This phase results from the existence of unfavourable conditions such as the necessity for microorganisms to acclimatize, the existence of significant changes in the temperature or the presence of toxic substances (Moore et al. 1976; Swamee and Ojha 1991). After this period, there is a fast increase in the use of oxygen resulting from the decomposition of organic compounds easily decomposed which finishes with the section almost horizontal (the plateau phase). Then, there is an increase of the curve caused by the further decomposition of carbon compounds (Swamee and Ojha 1991), which is explained by Keshavan (1965) as an endogenous respiration which depends on the concentration of the dissolved oxygen. If substrata are rich in the nitric compounds, there is the next increasing phase resulting from the consumption of oxygen for the needs of the nitrification process (Keshavan 1965; Anthonisen et al. 1976; Swamee and Ojha 1991; van Loosdrecht and Jetten 1998; Weijers 1999; Dmitriuk and Dojlido 2001).

The next phases which can be distinguished by analysing the results of the measurement cause difficulties in the modelling of the graph of the BOD changeability in the time function. Sheehy (1960) suggested assuming the connection between $\mathrm{BOD}_{t}$ values marked as $y$ on any day defined as $t$ with reference to final BOD marked as $L$.

$$
\frac{y}{L}=1-10^{-k \cdot t}
$$

Using the form of the formula (9), he calculated the constant $k$ for the individual days assuming as final $\mathrm{BOD}_{8}$. This way he received the set of values $k_{1 / 8}$, $k_{2 / 8}, \ldots k_{8 / 8}$. If the individual values were equal, he assumed that this was a reaction described with the equation of the first order, if the values are increasing, the lag phase occurs and the measurements from the first day should be rejected in modelling.

Numerous authors raised the doubts concerning the application of the equation of the first order to describe BOD. Adrian and Sanders (1992-1993), analysing the equation of Streeter and Phelps, introduced the differential calculus of the half order of the form:

$$
\frac{y}{t^{2}}=\frac{k_{1 / 2} \cdot L^{1 / 2}}{t}-\frac{k_{1 / 2}^{2}}{4}
$$

Constructing the diagram of the vertical axis $\frac{y}{t^{2}}$ and $\frac{1}{t}$ of the horizontal axis, the linear function is received whose 
mathematical description allows to indicate the constant $k_{1 / 2}$ and $L$.

Marske and Polkowski (1972) suggested the application of the model of the first order where $k<0.2$ (the formula 11) and otherwise the model of the second order (the formula 12)

$$
\begin{aligned}
& y=L \cdot\left(1-e^{-k \cdot t}\right) \\
& y=\frac{t}{\frac{1}{k \cdot L}+\frac{1}{L} \cdot t}
\end{aligned}
$$

suggesting the application of the model of the first order but the model of the second order. The doubts concerning the orders of the model were also raised by Young and Clark (1965), Hewitt et al. (1979), Borsuk and Stow (2000) and Mason et al. (2006).

Young and Clark (1965) compared the results received while applying the model of the first order and the second one. They noticed that the constants of the reaction for both cases are not the same therefore they marked the reactions of the first order by $k$ but the reactions of the second order by $K$. They wrote this reaction in the following form:

$$
\frac{d(L-y)}{d t}=K \cdot(L-y)^{2}
$$

Transforming the formula (13), they received the formula (14) in which the right side was created by the substitution of the parameters $a$ and $b$.

$$
y=\frac{t}{\frac{1}{K \cdot L^{2}}+\frac{1}{L} \cdot t}=\frac{t}{a+b \cdot t}
$$

Having transformed the formula (14), the linear form of the equation is received

$$
\frac{t}{y}=a+b \cdot t
$$

Using the method of the least squares, the parameters $a$ and $b$ can be calculated from the formulas (16) and (17), and with their use the values $L$ and $K$.

$$
\begin{aligned}
& a+b \cdot\left(\frac{\sum t}{t}\right)-\left(\frac{\frac{\sum t}{y}}{t}\right)=0 \\
& a+b \cdot\left(\frac{\sum t^{2}}{\sum t}\right)-\left(\frac{\frac{\sum t^{2}}{y}}{\sum t}\right)=0
\end{aligned}
$$

Young and Clark (1965) found out that in the scope of the research done by them the equation (14) adjusts well to the results of the measurement in scope without nitrification and gives the results with the similar accuracy to the equation of the first order.

Analysing the graph by Young and Clark (1965), Keshavan et al. (1965) confirmed the process of nitrification which disturbs the results of the BOD measurement. They distinguished 3 ranges in the dependence of the BOD function on the BOD time $=f(t)$. The first one is a dependence in which the use of oxygen occurs by the decomposition of available organic substances, in the second one there is an endogenous respiration which uses dissolved oxygen. In the third range nitrification occurs. 
The discussion on the model by Young and Clark (1965) was undertaken by Weber and Carlson (1965) suggesting that the application of least square method to solve the model of the second order is not necessary because this equation can be linearised. The equation by Thomas was the starting point

$$
\frac{d y}{d t}=\frac{k_{b}}{L}(L-y)^{2}
$$

which after integrating receives the form

$$
y=\frac{k_{b} \cdot L \cdot t}{1+k_{b} \cdot t}
$$

Transforming the equation (19) to the form

$$
\frac{1}{y}=\frac{1}{L}+\frac{1}{k_{b} \cdot L \cdot t}
$$

The linear dependence of the vertical axis $\frac{1}{y}$ and the horizontal axis $\frac{1}{t}$ can be received. Then, the intersection point with the vertical axis will indicate the value $\frac{1}{L}$ but $\frac{1}{k_{b} \cdot L}$ the function gradient.

The comparison of various modelling methods of the graph of the BOD changes was presented by Hewitt and Hunter (1975) who analysed 7 different models. They accepted the model by Reed-Theriault from 1927 as the reference one to which they referred the models by Rhame from 1956, Thomas from 1937, Fair from 1937, Sheehy from 1960, Moore et al. from 1960 and Navone from 1960. The authors found out that the deviations $k$ in relation to the reference method equalled even $50 \%$ but $L$ even $50.8 \%$. Despite of that they considered that the deviations from the value $k$ were bigger than $L$ as per 20 measurements the deviations over $10 \%$ occurred in a dozen of cases or more while calculating $k$ but in some while marking $L$. The method of Thomas (1937 after Hewitt and Hunter 1975) and Navone (1960) indicated the lowest errors in which the deviations exceeding $10 \%$ while calculating $k$ occurred respectively 8 and 7 times but while calculating $L$ twice for both methods. The dispersions in the calculated values $k$ and $L$ were an inspiration to modify the model. Hewitt et al. (1979) analysed the model of many orders. The starting point was the equation

$$
-\frac{d L_{i}}{d t}=K \cdot L_{i}^{n}
$$

which after integrating and transforming changes into the form (22)

$$
y=L-\left[(n-1) \cdot K \cdot t+L^{(1-n)}\right]^{1 /(1-n)}
$$

The authors calculated $K$ and $L$ for the equations of the orders from 1 to 4.0 with the step every 0.5 . They proved that the higher the value of the order $n$ is, the lower $K$ is and the higher $L$. They also found out that the values $L$ received by the application of the equation of the second order are bigger than the values received with the use of the equation of the first order with the multiplicity from 1.23 to 1.55 , the average of 1.39 . Young and Clark (1965) received the similar values and the relation received by them equalled about 1.25. As Hewitt et al. proved (1979), the lowest average square error related to the experimental 
results $L$ and the calculated one $L$ was for the equations of the second order.

Borsuk and Stow (2000) interpreted the equation (21) in another way because they marked the value $L_{i}$ as other BOD. Therefore, after integrating and substituting the relation between $L_{i}, y$ and $L$ as $L_{i}=L-y$, the formula (19) is expressed in the following form

$$
y=L-\left[L^{1-n}-k_{n} \cdot t \cdot(1-n)\right]^{1 /(1-n)}
$$

where $n$ was called "a pseudo order" of the equation but $k_{n}$ the constant of the reaction speed of the mixed order expressed as $\left(\mathrm{mg} \cdot \mathrm{dm}^{-3}\right)^{(1-\mathrm{n})} \cdot 24$ hours $^{-1}$.

Modelling the BOD changes in the sewages, Mason et al. (2006) suggested the application of the double exponential model. The model suggested by them is expressed by the formula

$$
y=L_{1} \cdot\left(1-e^{-k_{1} \cdot t}\right)+L_{2}\left(1-e^{-k_{2} \cdot t}\right)
$$

where $L_{1}$ and $L_{2}$ indicate the total BOD relatively. The index 1 refers to the contamination decomposed very easily and very quickly, and the index 2 the contamination decomposed more difficult and slower. The substances marked with the index 1 are the contamination which can also be decomposed in the anaerobic conditions or they can even, at the presence of oxygen in the result of its fast consumption, result in a such high temporary deficit of oxygen that the periodical occurrence of the anaerobic conditions is observed. The values $k_{1}$ and $k_{2}$ are the speed constant of the proper reactions. The total of $L_{1}$ and $L_{2}$ gives a total value of the total $L$. As Mason et al. (2006) stated, the double model indi- cates the bigger accuracy in comparison with the single model expressed in the formula (9) as the average square error for the double model was about $70 \%$ lower than such an error for the single model.

The influence of various parameters of the BOD changes on surface waters was examined by Ellis and Rodrigues (1995) analysing the 14 distinguished parameters such as the load of contamination, the time of water retention, the intensity and the duration of insolation, the pond depth, the precipitation, the water conductivity et al. with the lower influence. They proved the significant importance of many of these parameters and especially the insolation and the precipitation. It is worth mentioning that the decrease in the BOD concentration in water of the pond proves the existence of the favourable process in it which is self-purification.

Anthonisen et al. (1976) and Dmitruk and Dojlido (2001) examined the influence of the process of nitrification on the value of $\mathrm{BOD}_{5}$ received from the measurement. Dmitruk and Dojlido (2001) divided each sample into two parts and they measured $\mathrm{BOD}_{5}$ in each one but they added 2-chloro-6-trichlorometylpiridinum (TCMP) into one of them, which inhibits the process of nitrification. This way the received result for the second sample was a value of the carbon $\mathrm{BOD}_{5}$ which is referred to the measurement of organic carbon. The difference of the results of both measurements allowed to define nitric $\mathrm{BOD}_{5}$. They found out that nitric $\mathrm{BOD}_{5}$ in case of surface waters, i.e. low $\mathrm{BOD}_{5}$ concentrations reached $15 \%$, but in case of purified sewages, i.e. at the higher concentrations even $50 \%$. These results should be taken into account care- 
fully because the samples were not too numerous. The authors suggest that both measurements should be separated and both values of $\mathrm{BOD}_{5}$ interpreted separately in the European directives.

Anthonisen et al. (1976) examined the influence of free $\mathrm{NH}_{3}$ concentration and nonionized $\mathrm{HNO}_{2}$ on the inhibition of the nitrification process. They found out that both compounds are inhibitors of nitrification and their concentrations have a much more significant influence than the total concentration of $\mathrm{N}-\mathrm{NH}_{4}$ and $\mathrm{N}-\mathrm{NO}_{2}$. They found out the significant influence of the reaction $(\mathrm{pH})$ on this process and first of all on the participation of both inhibitors. There is an inhibition of both the Nitrosomonas bacteria and the Nitrobacter ones present at the higher reactions, however there is the increasing concentration of $\mathrm{HNO}_{2}$ influences the inhibition of the Nitrobacter bacteria at the lower ones.

Van Loosdrecht and Jetten (1998) found out that heterotrophy nitrification probably has a significant influence on the concentrated sewages when there is a high ratio of $\mathrm{COD} / \mathrm{N}$ and it is higher than 10. However the anaerobic oxidation of ammonia occurs only in the autotrophic systems with the long period of sediment retention.

Matejczuk and Grabarski (1995) based their study on the model by Michaelis-Menten elaborating the method of the constant BOD measurement. The idea is based on the 3-minute BOD measurement which is calculated into the value of $\mathrm{BOD}_{5}$. Testing the accuracy of the model they found out that the deviations between the 3-minute measurement and the classic $\mathrm{BOD}_{5}$ one were minimal.

\section{SUMMARY}

As it was observed, numerous factors influence the distribution of points defining the changes in BOD, which include the concentration of the organic contamination and various disturbing factors such as salinity, poisons, etc. Kovarowa-Kovar and Egli (1998) found out that the growth of microorganisms is limited both by the availability of organic carbon and its limitations as well as depending on the access to other nutrients such as nitrogen and phosphorus.

Nitrification occurs in the first 5 days of incubation as the nitrification inhibitor distinctly lowered the values of the measurement points. It can be said approximately that the nitrification includes about $10 \%$ of the value of $\mathrm{BOD}_{5}($ Siwiec et al. 2012).

In spite of the fact that there is possible to find in literature a large number of various models describing the time changes of $\mathrm{BZT}_{5}$, not all of them do it correctly. There is shown (Siwiec et al. 2012) that the second order models approximate the measurement points in a better way than the first order or half order models.

\section{REFERENCES}

ADRIAN D.D., SANDERS T.G. 1992-1993: Oxygen sag equation for half order BOD kinetics. Journal of Environmental Systems, 22, (4), 341-351.

ADRIAN D.D., SANDERS T.G. 1998: Oxygen sag equation for second-order BOD decay. Water Research, 32, (3), 840-848.

ANTHONISEN A.C., LOEHR R.C., PRAKASAM T.B.S., SRINATH E.G. 1976: Inhibition of nitrification by ammonia and nitrous acid. Journal of Water Pollution Control Federation, $48,(5), 835-852$. 
BORSUK M.E., STOW C.A. 2000: Byesian parameter estimation in a mixed-order of BOD decay. Water Research. 34, (6), 1830-1836.

CHEE G.J., NOMURA Y., IKEBUKURO K., KARUBE I. 2000: Optical fiber biosensor for the determination of low biochemical oxygen demand. Biosensors \& Bioelectronics, 15, 371-376.

DMITRUK U., DOJLIDO J. 2001: BZT 5 węglowe i BZT $_{5}$ azotowe w wodach powierzchniowych i ściekach. Gaz, Woda i Technika Sanitarna, (8), 287-289.

ELLIS K.V., RODRIGUES P.C.C. 1995: Multiple regression design equations for stabilization ponds. Water Research, 29, (11), 2509-2519.

FUJIMOTO Y. 1964: Graphical use of first stage BOD equation. Journal of Water Pollution Control Federation, 36, (1), 69-71.

GAJKOWSKA-STEFAŃSKA L., GUBERSKI S., GUTOWSKI W., MAMAK Z., SZPERLIŃSKI Z. 1994: Laboratoryjne badania wody, ścieków i osadów ściekowych, cz. 2, Oficyna Wydawnicza Politechniki Warszawskiej, Warszawa.

HEWITT J.P., HUNTER J.V. 1975: A comparison of the methods used to calculate first order BOD equation constants. Water Research, 9, 683-687.

HEWITT J.P., HUNTER J.V., LOCKWOOD D. 1979: A multiorder approach to BOD kinetics. Water Research, 13, 325-329.

KESHAVAN K., WEBER W.J., CARLSON R.H. 1965: Discussion to "Second order equation for BOD" by Young J.C. and Clark J.W. Journal of the Sanitary Engineering Division ASCE, 91, (SA3), pp. 136-140.

KIEDRYŃSKA L., PAPCIAK D., GRANOPS M. 2006: Chemia sanitarna, Wydawnictwo SGGW, Warszawa.

KOVAROVA-KOVAR K., EGLI T. 1998: Growth kinetics of suspended microbial cells: from single-substrate-controlled growth to mixed-substrate kinetics. Microbiology and Molecular Biology Reviews, vol. 62, September 1998, no 3, pp. 646-666.

LIU J., OLSSON G., MATTIASSON B. 2004: Short-term BOD $\left(\mathrm{BOD}_{\mathrm{st}}\right)$ as a parameter for on-line monitoring of biological treatment process. Part I. A novel design of BOD biosensor for easy renewal of bio-receptor. Biosensors \& Bioelectronics, 20, 562-570.
MARSKE D.M., POLKOWSKY L.B. 1972: Evaluation of methods for estimating biochemical oxygen demand parameters. Journal of Water Pollution Control Federation, 44, (10), 1987-2000.

MASON I.G., MCLACHLAN R.I., GERARD D.T. 2006: A double exponential model for biochemical oxygen demand. Bioresource Technology, 97, 273-282.

MATEJCZUK W., GRABARSKI P. 1995: Ciagły pomiar BZT jako ważny czynnik ekonomiczny w oczyszczalniach ścieków i zakładach przemysłowych. Gaz, Woda i Technika Sanitarna, (7), 223-226.

MOORE E.W., THOMAS H.A., SNOW W.B. 1950: Simplified method for analysis of BOD data. Sewage and Industrial Wastes, October, 1343-1355.

NAVONE R. 1960: A new method for calculating $\mathrm{K}$ and L for sewage. Water \& Sewage Works, July, 285-286.

REYNOLDS D.M., AHMAD S.R. 1997: Rapid and direct determination of wastewater BOD values using a fluorescence technique. Water Research, 31, (8), 2012-2018.

SHEEHY L.P. 1960: Rapid methods for solving first-order equations, Journal of Water Pollution Control Federation, 32, (6), 646-652.

SIWIEC T., KIEDRYŃSKA L. ABRAMOWICZ K., REWICKA A.: Analysis of chosen models describing the changes in $\mathrm{BOD}_{5}$ in sewages. Environment Protection Engineering (in printing after review, 2012 no 2).

SOHN M.J., LEE J.W., CHUNG C., IHN G.S., HONG D. 1995: Rapid estimation of biochemical oxygen demand using a microbial multi-staged bioreactor. Analytica Chimica Acta, 313, 221-227.

SWAMEE P.K., OJHA C.S.P. 1991: Modelling of BOD exertion curve. Water Research, 25, (7), 901-902.

TEBBUTT T.H.Y., 1976: Respirometric determination of BOD., Water Research, 10, 613-617.

THOMAS H.A. 1950: Graphical determination of BOD curve constants. Water \& Sewage Works, March, 123-124.

VAN LOOSDRECHT M.C.M., JETTEN M.S.M. 1998: Microbiological conversions in nitrogen removal. Water Science and Technology, 38, (1), $1-7$. 
WEBER W.J., CARLSON R.H. 1965: Discussion to "Second order equation for BOD" by Young J.C. and Clark J.W. Journal of the Sanitary Engineering Division ASCE, 91, (SA3),140-147.

WEIHERS S.R. 1999: On BOD tests for the determination of biodegradable COD for calibrating activated sludge Model No 1. Water Science and Technology, 39, (4), 177-184.

XINGLONG J., BOYD C.E. 2005: Measurement of 5-day biochemical oxygen demand without sample dilution or bacterial and nutrient enhancement. Aquacultural Engineering, 33, 250-257.

YOUNG J.C., CLARK J.W. 1965: Second order equation for BOD. Journal Sanitary Engineering Division ASCE 91, (SA1), pp. 43-57.

Streszczenie: Charakterystyka metod oznaczania oraz wybranych modeli opisujacych zmiany $B Z T_{5} w$ ściekach. W artykule przedstawiono metody pomiaru BZT w ściekach i charakterystykę różnych modeli, które można stosować do opisu zmian BZT. Przedstawiono modele Moore'a (Moore i inni 1950) Thomasa, (Thomas 1950), Navone (Navone 1960), Fujimoto (Fujimoto 1964), Hewitta (Hewitt i inni 1979) oraz Adriana i Sandersa (Adrian i Sanders 1992-1993), jak również model Yaung'a i Clark'a (Young i Clark 1965) wykorzystywany przez Adriana i Sandersa (Adrian i Anders 1998), Borsuka i Stowa (Borsuk i Stow 2000) oraz Mansona (Manson i inni 2006). Porównanie modeli sugeruje, że zmiany BZT w czasie, są lepiej opisane przez modele drugiego rzędu lub podwójnie wykładnicze niż modele pierwszego rzędu.

\section{MS. received October 2011}

\section{Authors' address:}

Tadeusz Siwiec, Lidia Kiedryńska, Klaudia Abramowicz, Aleksandra Rewicka Zakład Wodociągów i Kanalizacji Katedra Inżynierii Budowlanej Wydział Budownictwa i Inżynierii Środowiska Szkoła Główna Gospodarstwa Wiejskiego ul. Nowoursynowska 166

02-787 Warszawa

Poland

e-mail:

tadeusz_siwiec@sggw.pl lidia_kiedrynska@sggw.pl k_abramowicz@wp.pl Aleksandra.Rewicka@europe.ppdi.com 